Avalaible online: https://ejournal.iai-tribakti.ac.id/index.php/pgmi

Article doi: https://doi.org/10.33367/jiee.v3i2.1876

Submission: 2021-7-29 Revision: 2021-8-19 Accepted: 2021-8-19

\title{
Improving Student Learning Outcomes During Covid-19 Pandemic Using Learning Videos and E-Learning
}

\author{
A. Jauhar Fuad 1, Pranita Andhinasari 2 \\ ${ }^{1}$ Institut Agama Islam Tribakti Kediri, ${ }^{1}$ Institut Agama Islam Tribakti Kediri \\ 1 info.ajauharfuad@gmail.com; ${ }^{2}$ pranitaandhinasari@gmail.com
}

\begin{abstract}
The problem that arises in learning in the Covid-19 era is unilateral learning centered on teacher activities, by giving assignments. Students only work on assignments and then the work is photographed and sent via whatsapp, causing students to lack understanding of the material and reluctant to do assignments. The solution to the problems above is the use of video for learning and e-learning. This research phase begins with action planning, action implementation, observation and reflection. This stage is repeated until the expected increase in learning outcomes is achieved, and does not require further improvement. The final result analysis showed that in the pre-learning cycle the percentage of classical completeness was $27.28 \%$. In the first cycle there was an increase in classical completeness reaching $54.5 \%$. In the second cycle there was an increase in classical completeness reaching 91\%. Thus, it can be concluded that the use of video for learning and e-learning during the covid-19 pandemic is able to improve student learning outcomes.
\end{abstract}

Keyword: Learning Outcomes, Covid 19 Pandemic, Learning Videos and ELearning

\begin{abstract}
Abstrak
Permasalahan yang muncul dalam pembelajaran di era Covid-19 adalah pembelajaran sepihak yang dipusatkan pada kegiatan guru. Dengan pemberian tugas siswa hanya mengerjakan tugas kemudian karya tersebut difoto dan dikirim melalui whatsapp sehingga menyebabkan siswa kurang memahami materi dan enggan mengerjakan tugas. Solusi dari permasalahan di atas adalah pemanfaatan video untuk pembelajaran dan e-learning. Tahap penelitian ini dimulai dengan perencanaan tindakan, pelaksanaan tindakan, observasi dan refleksi. Tahap ini diulangi sampai tercapai peningkatan hasil belajar yang diharapkan, dan tidak memerlukan perbaikan lebih lanjut. Analisis hasil akhir menunjukkan bahwa pada siklus pra pembelajaran persentase ketuntasan klasikal sebesar 27,28\%. Pada siklus I terjadi peningkatan ketuntasan klasikal mencapai 54,5\%. Pada siklus II terjadi peningkatan ketuntasan klasikal mencapai 91\%. Dengan demikian, dapat disimpulkan bahwa pemanfaatan video untuk pembelajaran dan e-learning di masa pandemi covid-19 mampu meningkatkan hasil belajar siswa.
\end{abstract}

Kata Kunci: Hasil Pembelajaran, Pandemi Covid 19, dan Video Pembelajaran dan E-Learning 


\section{Introduction}

The results of observations and sharing of experiences between classroom teachers during Teacher Working Group (KKG) activities, where many find it difficult and confused in applying and delivering online learning materials on social media. The results of the study explain that during a pandemic like this, there is a prohibition against face-toface learning, so that it becomes a big influence on student learning outcomes, namely by looking at the low student evaluation scores ${ }^{1}$.

Some of the problems that occurred during the learning took place, among others. First, distance online learning using whatsaap groups is less effective in being used in the learning process. Second, students are less interested in creative and independent learning. Third, learning becomes monotonous because only assignments are given. Fourth, the lack of variety of learning models makes students bored in following the learning process ${ }^{2}$. Fifth, there are 11 students of class $V$, in learning the material for theme 9 subtheme 2 there are only 3 students (27.28\%) whose scores reach the

\footnotetext{
${ }^{1}$ In Setyorini, "Pandemi COVID-19 Dan Online Learning: Apakah Berpengaruh Terhadap Proses Pembelajaran Pada Kurikulum 13?," Journal of Industrial Engineering \& Management Research 1, no. 1 (July 5, 2020): 95-102, https://doi.org/10.7777/jiemar.v1i1.31.

2 Sri Gusty et al., Belajar Mandiri: Pembelajaran Daring di Tengah Pandemi Covid19 (Yayasan Kita Menulis, 2020).

${ }^{3}$ Susi Sihombing et al., "Analisis Minat Dan Motivasi Belajar, Pemahaman Konsep Dan Kreativitas Siswa Terhadap Hasil Belajar el Bidayah: Journal of Islamic Elementary Education Volume 3, Nomor 2, September 2021
}

Minimum Completeness Criteria. While the Minimum Completeness Criteria set by the teacher in thematic learning is 75 .

Based on these results, researchers tried to improve learning related to learning outcomes. The results of the learning reflection of theme 9 subtheme 2 when using the assignment method via WhatsApp group, low learning interest. The results of the study explain that low interest in learning will have an impact on low learning outcomes ${ }^{3}$.

Efforts to improve learning, among others, by using appropriate learning methods, namely fun learning. This can encourage students to study online from home more optimally ${ }^{4}$. In Indonesia, online learning is regulated in the Circular Letter of the Ministry of Education and Culture Number 4 of 2020 concerning the Implementation of Education in the Emergency Period of Corona Virus Disease (Covid-19). Regarding policies related to online learning that must be considered. First, online learning must provide a meaningful learning experience ${ }^{5}$. Second, this learning can be focu-

Selama Pembelajaran Dalam Jaringan," Jurnal Pendidikan Matematika: Judika Education 4, no. 1 (June 27, 2021): 41-55, https://doi.org/10.31539/judika.v4i1.2061. ${ }^{4}$ Albert Efendi Pohan, Konsep Pembelajaran Daring Berbasis Pendekatan Ilmiah (Riau: Penerbit CV. Sarmu Untung, 2020).

5 Ilham Baharuddin, "Pembelajaran Bermakna Berbasis Daring Di Tengah Pandemi COVID-19," Kelola: Journal of Islamic Education Management 5, no. 2 (November 16, 2020): 7988, https://doi.org/10.24256/kelola.v5i2.1377. 
sed on education about life skills ${ }^{6}$. Third, from one student to another about learning activities and tasks may vary according to their respective interests and conditions, including taking into account the gap in access/learning facilities at home ${ }^{7}$.

One alternative solution that can improve student learning outcomes in learning theme 9 sub-theme 2 is one of them by applying the use of learning videos and school E-Learning. The use of video media in learning can complement basic experiences when students read and increase student motivation and instill attitudes and other affective aspects ${ }^{8}$. Using E-Learning, students are able to manage their own study time by getting teaching materials from their respective places ${ }^{9}$. This learning can train students' independence and hone students' creativity.

The application of the use of learning videos and E-Learning can

${ }^{6}$ Dimas Nugroho and Yudha Nurdian, "Pemicuan Pendidikan Kecakapan Hidup Anak Era Pandemi di Sumbersari Jember," GERVASI: Jurnal Pengabdian kepada Masyarakat 5, no. 1 (May 2, 2021): 13-24,

https://doi.org/10.31571/gervasi.v5i1.1955.

${ }^{7}$ Henry Aditia Rigianti, "Kendala

Pembelajaran Daring Guru Sekolah Dasar Di Banjarnegara," Elementary School: Jurnal Pendidikan Dan Pembelajaran Ke-SD-An 7, no. 2 (July 1, 2020), https://doi.org/10.31316/esjurnal.v7i2.768.

8 Andrianto Andrianto, "The Role of Audio Visual Media In Increasing Interst In Learning Islamic Religious Education In Sdn Teloko," Abdau: Jurnal Pendidikan Madrasah Ibtidaiyah 4, no. 1 (July 1, 2021): 71-91, https://doi.org/10.36768/abdau.v4i1.177.

${ }^{9}$ Sobron Adi Nugraha, Titik Sudiatmi, and Meidawati Suswandari, "Studi Pengaruh Daring Learning Terhadap Hasil Belajar Matematika Kelas IV," Jurnal Inovasi Penelitian 1, no. 3 (July 24, 2020): 265-76, 104 improve student learning outcomes 10. Student learning outcomes using learning videos and e-learning have increased from cycle I to cycle II. With the learning video, it is expected that learning can achieve maximum results because the use of media, one of which is video media. If the video is well packaged and supported by information delivery facilities such as internetassisted e-learning and appropriate learning styles, this learning capacity will be better which in turn will provide better results ${ }^{11}$.

The use of learning videos and ELearning requires the role of students to learn actively, creatively and independently. In addition, teachers are required to be able to further improve skills and innovation. Teachers in carrying out online or distance learning as well as providing motivation and generating student learning activities in mastering the subject matter so as to improve

https://doi.org/10.47492/jip.v1i3.74; Atalah Raniah et al., "Dampak Pandemi Terhadap Pemanfaatan E-Learning Pada Sekolah Dasar Di Den Haag," Islamic Review: Jurnal Riset Dan Kajian Keislaman 10, no. 1 (April 26, 2021): 111-24, https://doi.org/10.35878/islamicreview.v10i1. 251.

${ }^{10}$ Eri Susmiati, "Meningkatkan Motivasi Belajar Bahasa Indonesia Melalui Penerapan Model Discovery Learning Dan Media Video Dalam Kondisi Pandemi Covid-19 Bagi Siswa SMPN 2 Gangga," Jurnal Paedagogy 7, no. 3 (August 13, 2020): 210-15, https://doi.org/10.33394/jp.v7i3.2732.

11 Putri Oktavia Damayanti, "Efektivitas Media Video Berbasis Powerpoint Dalam Pembelajaran Daring Terhadap Hasil Belajar Tema 7 Subtema 3 Di Kelas IV B MINU Ngingas Waru Sidoarjo" (undergraduate, UIN Sunan Ampel Surabaya, 2021), http://digilib.uinsby.ac.id/48170/. 
student learning outcomes. Then the research problem can be formulated as follows: What are the steps for using learning videos and E-Learning with theme 9 sub-theme 2 class V SD Negeri 6 Klodan Nganjuk? how to improve Method

The subjects of this study were fifth grade students of SD Negeri 6 Klodan, Ngeos District, Nganjuk Regency, semester 2 of the 2020/2021 academic year. The subject matter is theme material 9 sub-theme 2 which includes three subjects. This research was carried out during May 2021. The learning improvement research procedure was designed into 2 cycles, starting with the pre-cycle and then the first cycle. If problems were found, it was continued in the second cycle. The cycle will end when the problem has been resolved with a Minimum Learning Mastery Standard of 85\%. The research procedure is carried out in 4 stages whose sequence is planning, implementtation, observation and reflection.

Qualitative data analysis was conducted to describe the results of field observations. Data collection through observation was carried out by researchers in order to obtain learning

\section{Result and discussion \\ Result}

\section{Pre Cycle}

In the pre-cycle planning activity there are several tools that must be prepared, including the Learning Implementation Plan (RPP), student worksheets and evaluation test sheets. The test sheet used in the form of a question sheet consisting of 10 student learning outcomes during the Covid 19 pandemic using learning videos and E-Learning theme 9 subtheme 2 class V SD Negeri 6 Klodan Nganjuk

outcomes that have been achieved, namely by providing evaluation questions sent via e-Learning and photo documentation of assignments. Qualitative data is presented in sentences separated by category to obtain conclusions. The presentation of quantitative data is described in the form of percentages and numbers. In calculating the percentage of student learning outcomes, it is adjusted to the criteria for learning completeness which are grouped into two categories, namely complete and incomplete categories. The criteria are as follows, Minimum Completeness Criteria (KKM) on theme material 9 sub-theme 2 at SD Negeri 6 Klodan Kec. Ngetos Kab. Nganjuk is 75 . Furthermore, it is explained, if $85 \%$ of the number of students in the class who take part in teaching and learning activities (KBM) achieve success in the complete category, then the process of improving student learning is said to be successful.

evaluations that have been equipped with a scoring rubric.

Learning activities carried out in class V SD Negeri 6 Klodan are online learning using the WhatsApp group written message application. In carrying out the activities the teacher gives the students to observe the reading text. The teacher gives assignments to students by working on questions in the student 
book. The teacher sends evaluation questions via whatsapp group. The teacher gives directions to students to send proof of the results of the work through the whatsapp group.

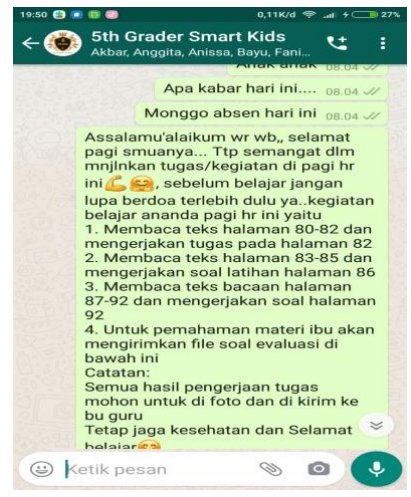

Figure 1. Teacher Delivers Materials and Assignments Via Whatsapp Group Written Messages

In this activity, learning is only one-way centered on the activities of the teacher. Students only work on assignments and then the results of the work are photographed and sent via whatsapp. Because online learning activities have not varied in using media only assignments, so that some students still do not understand the material correctly. And there are some students who look lazy or reluctant in doing assignments.

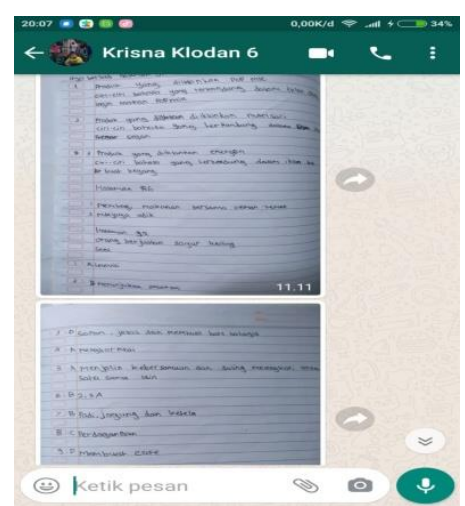

Figure 2. Results of Student Assignments Submitted Via Whatsapp Group
At the end of the lesson the teacher gives an evaluation to the students in the form of daily test questions. The results of daily tests for fifth grade students on theme 9 sub-theme 2 are as follows:

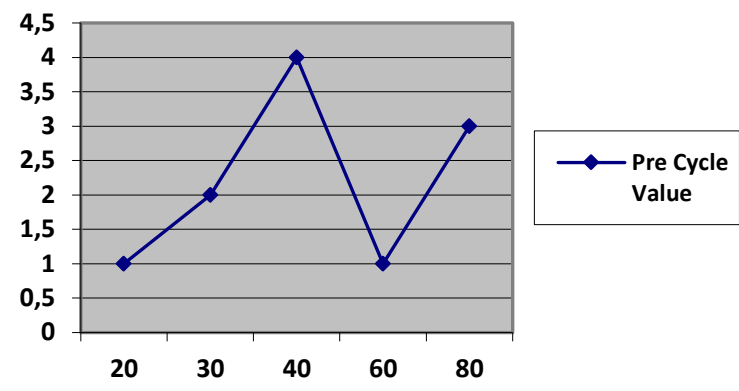

Figure 3. Pre-Cycle Student Learning Test Results

If seen in figure 3 , of the 11 fifth grade students who scored above the KKM only 3 students (27.28\%). Students who scored below the KKM were 8 students (72.72) with an average grade $\mathrm{V}$ grade of 49.09 .

After analyzing the learning outcomes, the teacher reflects to find out the shortcomings in the learning process so that it can be used as a reference in the preparation of learning improvements. Weaknesses that need to be improved: (1) In learning activities, it is only centered on teacher activities through assigning assignments; (2) The teacher only directs students to understand the material, students who have less ability will remain confused in understanding the material; (3) Students are less interested in the learning activities carried out by the teacher; (4) The method used is still not right.

\section{Cycle I}

The preparation of learning improvement activity plans includes: designing online Learning Implementation Plans (RPP) using learning videos and e-Learning according to theme material 9 sub-theme 2, desig- 
ning question grids, designing teaching materials, designing Student Activity Sheets (LKPD), designing learning online using learning videos and eLearning. This was done because of the corona virus which forced them to stay at home and study from home and designed evaluation questions for theme 9 sub-theme 2 to find out the learning outcomes of fifth grade students after

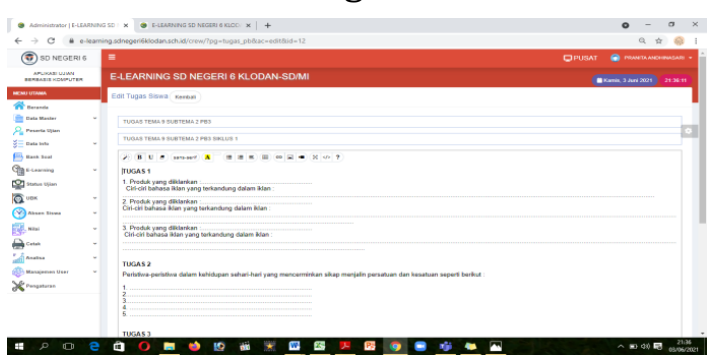

using learning videos and E-Learning.

At the first cycle meeting, the implementation of teaching and learning activities was carried out using learning videos and e-Learning. Through the written message application in the WhatsApp group, the teacher conveys information about the assignment.

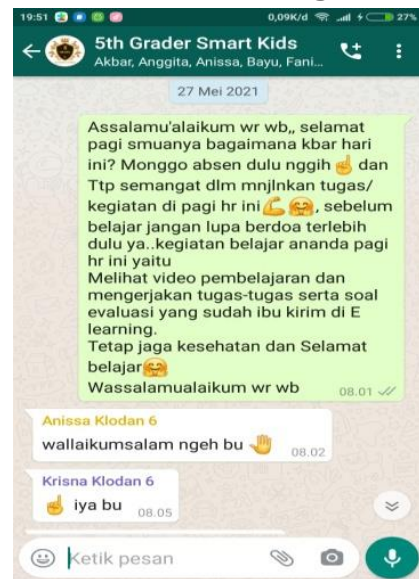

Figure 4. Task Notifications Via Whatsapp Group Cycle

In the initial activity, the teacher provides apperception in the form of questions by exploring student experiences that are relevant to the theme. The teacher conveys the theme/ subtheme, learning objectives and learning activities that will be carried out today. The teacher reads the narrative text in the student's book. After finishing reading, the teacher gives direction to the students to observe the television advertisement that is broadcast by the teacher.

After observing the advertisement image, the teacher explains the contents of the text material in the student's book. The teacher reinforces the material and concludes the language characteristics contained in the advertisement. The teacher gives an explanation of the procedures for doing assignments in eLearning. Teacher gives Task 1 in eLearning.

The teacher shows pictures that reflect the importance of unity and oneness. The teacher reads the material text about pictures in the student book where this text is used to bridge with the previous material. The teacher gives an affirmation of the material about the

Figure 5. Assignment Through E-Learning Cycle I

importance of the unity and integrity of the Indonesian nation. The teacher gives Task 2 in e-Learning. The teacher shows pictures of economic activities in student books. The teacher explains the content of the material. The teacher reiterates the types of economic enterprises in society. The teacher gives Task 3 in e-Learning. To measure learning outcomes, students are given a test at the end of the lesson.

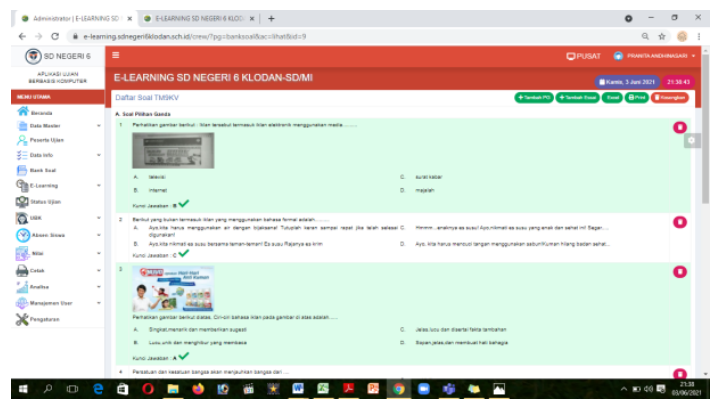

Figure 6. Cycle I Test Questions

The results of this test will be used as a parameter for achieving the formulated learning objectives. The 
teacher draws conclu-sions/summaries of learning outcomes.

Based on the implementation of increased learning, the following results were obtained:

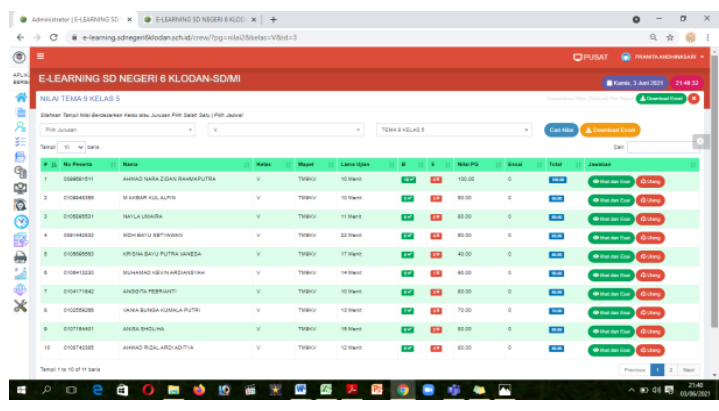

Figure 7. Cycle I Test Results in E-Learning

If Figure 7 is presented in the form of a graph of the learning outcomes of the first cycle, then it is as follows:

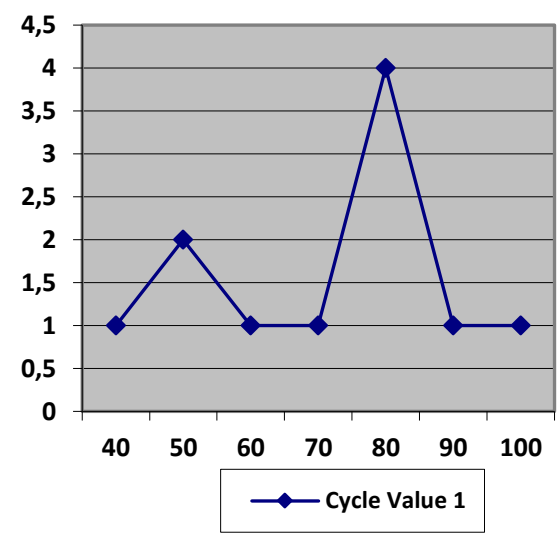

Figure 8. Student Learning Test Results Cycle I

If seen in figure 8, of the 11 fifth grade students in this first cycle activity who scored above the KKM or completed there were 6 students (54.5\%) and students who scored below the KKM or had not completed there were 5 students $(45,5 \%)$ with the average value of class $\mathrm{V}$ students is 70.9 . With this online learning, the delivery of material from the teacher is very short. The teacher provides a learning video where the video can be accessed via ELearning. As a result, students only watch the teacher's explanation via video and cannot ask questions directly. Because the teacher can't and the lack of variation in learning, so it affects lear- ning outcomes when an evaluation test is held at the end of the cycle. Based on data analysis in cycle I, the indicators of success have not been met due to several reasons, including: (1) Limited time in carrying out learning because the learning used is online. (2) Due to online learning, teachers have not been able to supervise students in doing practice questions and even some students are done by their parents.

The results of the reflection in cycle I there are several ways to overcome these problems, including: (1) The teacher prepares more learning videos to the maximum so that the videos are easier to understand, interesting, and creative by providing more concrete examples. So that learning can be maximized even with a very limited time. (2) The teacher must also directly assess and evaluate each student's work so that students know where the mistakes are made and do not repeat the mistakes again if students are given similar questions. Here the teacher's step is to provide practice questions through E-Learning where students can immediately find out the correct answer. (3) The teacher motivates students by creating a relaxed and fun learning atmosphere when learning online so that students are not tense and want to do their own work. (4) If the learning is not clear, students can share through voive notes or videos, then the teacher gives feedback.

The percentage of test results in the first cycle has not reached classical learning completeness in accordance with the Minimum Learning Mastery Standard (SKBM) which is $85 \%$, it is necessary to increase learning in planning, implementing learning in cycle II. It is hoped that after the second cycle, students' final test results can improve and achieve completeness in accordance with the predetermined Minimum 
Learning Accomplishment Standards (SKBM).

\section{Cycle II}

The preparation of this learning improvement includes: preparing a Learning Implementation Plan (RPP) using learning videos and E-Learning according to the theme material 9 subthemes 2. Preparing E-Learning by inserting learning videos, preparing evaluation questions and answer keys that will be submitted in learning, preparing a grid -Evaluation grid, preparing teaching materials, preparing student worksheets (LKPD).

Figure 10. Assignment through E-Learning

$$
\text { Cycle II }
$$

At the second cycle meeting, the implementation of teaching and learning activities was carried out using learning videos and e-Learning. Through the whatsapp written message application, the teacher group conveys information about assignments.

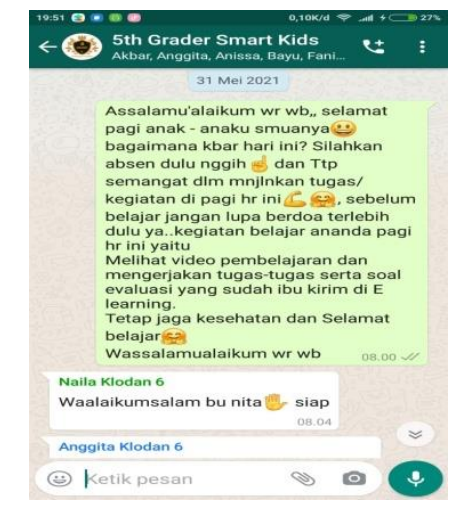

Figure 9. Task Notifications Through Whatsapp Group Cycle II

In the initial activity, the teacher provides apperception in the form of questions by exploring student experiences that are relevant to the theme. The teacher conveys the theme/ subtheme, learning objectives and learning activities that will be carried out today. The teacher reads the narrative text in the student's book. After finishing reading, the teacher shows an example of an image of a television advertisement.
After observing the advertisement image, the teacher explains the content of the text material in the student book. The teacher reinforces the material and concludes the language characteristics contained in the advertisement. The teacher gives Task 1 in E-Learning.

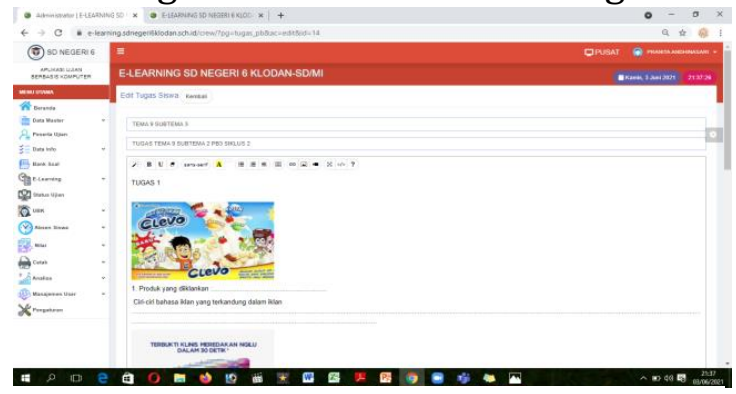

Figure 11. Cycle II Evaluation Test Questions

The teacher shows pictures that reflect the importance of unity and oneness. The teacher reads the material text about pictures in the student book where this text is used to bridge with the previous material. The teacher emphasized the importance of the unity and integrity of the Indonesian nation. The teacher explains examples of events in everyday life as a form of reflection on the attitude of establishing unity and oneness. The teacher gives Task 2 in eLearning. The teacher shows pictures of examples of Indonesian people's economic activities in student books. The teacher explains the content of the material. The teacher reiterates the types of economic enterprises in Indonesian society. The teacher gives Task 3 in e-Learning. To measure learning outcomes, students are given a test at the end of the lesson. The results of this test will be used as a parameter for achieving the formulated learning

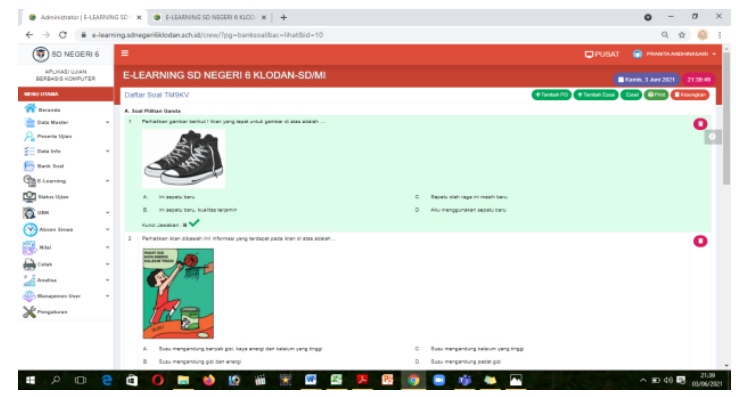


objectives. The teacher draws conclusions/summaries of learning outcomes.

Based on the implementation of increased learning, the following results were obtained:

If Figure 12 is presented in the form of a graph of the learning outcomes of the first cycle, it is as follows:

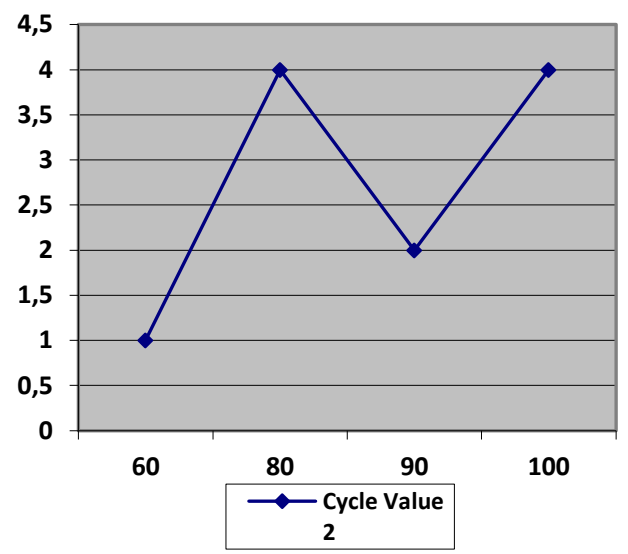

Figure 13. Student Learning Test Results

If seen in graph 13, from 11 students in class $\mathrm{V}$ the test results that have been carried out in cycle II activities are students who get scores above the KKM or complete there are 10 students (91\%) and students who get scores below the KKM or have not completed there are 1 student (9\%) with an average grade $V$ grade of 87.3.

\section{Discussion}

In the pre-cycle stage, the researcher only used the assignment method. In this activity, learning is only one-way centered on the activities of the teacher. Students only work on assignments and then the results of the work are photographed and sent via whatsapp. Because online learning ac-tivities have not varied in using media only assignments, so that some students still do not understand the material correctly. And there are some students who look lazy or reluctant in doing assignments.
Based on the learning mastery test data and observation data in the second cycle, the following conclusions were obtained: (a) Learning using learning videos and e-Learning was in accordance with the plan in the lesson plan so that learning could go according to plan. (b) The classical mastery of student learning is $91 \%$, so that the indicator of the success of classical mastery reaches $85 \%$. It can be said that the cycle has ended. However, there is still 1 student who has not finished studying. This is because the level of the student's ability is indeed lacking, so for further actions

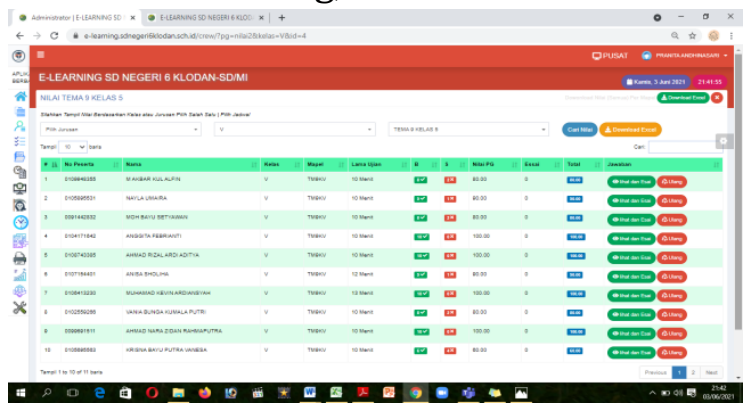

Figure 12. Cycle II Evaluation Test Results in ELearning

the unfinished student is given separate guidance outside class hours on material that has not been understood, then remedial is given until the specified completeness can be achieved.

In the first cycle, the teacher began to use learning videos and E-Learning. The use of this media is very appropriate and effectively used to convey learning. Because online learning using learning videos and E-Learning is done because of the Corona virus which forces people to stay at home and learn from home. By using E-Learning students can immediately know the assessment so that students know the location of the error and do not repeat the error again if students are given similar questions. Here the teacher's step is to provide practice questions through E-Learning where students can immediately find out the correct answer. 
In the second cycle, student learning completeness continues to increase, starting from the pre-cycle learning to the second cycle learning. There is only 1 student out of 11 students whose score is still below the KKM in cycle II. The learning improvement activities were successfully carried out until the second cycle stage. It turns out that by using the right method in accordance with the learning objectives, students can absorb the material presented so that the expected learning outcomes can be achieved.

Increased student learning activities starting from cycle I to cycle II, students are motivated and interested in following the lesson as indicated by the increased attention of students. In the results of the evaluation of learning outcomes in cycle II, the percentage of students' completeness increased, in the 9th sub-theme 2 material from $45.5 \%$ to $91 \%$ of 11 students. Based on the Minimum Completeness Criteria, which is $85 \%$, the learning improvement process is said to be complete because it has exceeded $85 \%$ So there is no need for follow-up to improve learning.

Based on the recapitulation of learning outcomes can be shown in the following diagram:

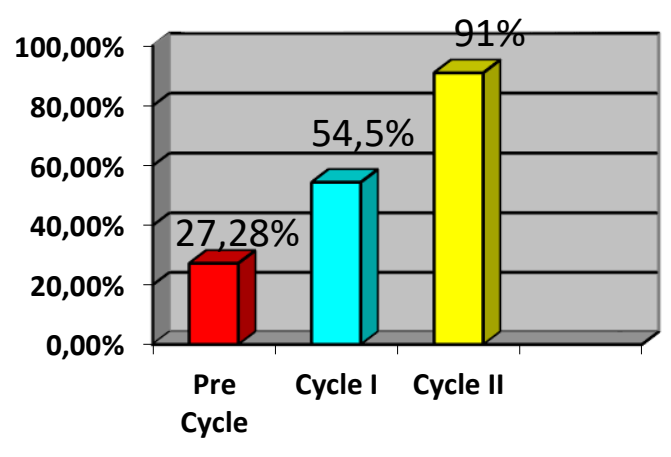

口Pre Cycle $\quad$ QCycle I $\quad$ 口Cycle II

Figure 14. Complete Learning Outcomes Per Cycle

Based on diagram 1, in this study it can be explained that using learning videos and E-Learning improves student learning outcomes, namely in pre-cycle activities the percentage of learning achievement is only $27.28 \%$ with an average of 49.09 . In the first cycle the percentage of learning outcomes rose to $54.5 \%$ with an average of 70.9 . While in the second cycle of activities the percentage of learning outcomes rose to 91\% with an average of 87.3.

Thus, the selection of the use of learning videos and E-Learning is very appropriate during a pandemic where learning is carried out online or learning from home with theme material 9 subtheme 2 can run effectively and smoothly. This can be proven by the existence of research using learning videos and using E-Learning.

Research findings suggest that the use of video media in learning can complement basic experiences when students read and increase student motivation and instill attitudes and other affective aspects 12 . Research

Apriyanti, “Peningkatan Motivasi Belajar Siswa Dalam Pembelajaran Pkn Menggunakan Media Audiovisual Kelas IV," Jurnal Pendidikan Dan Pembelajaran Khatulistiwa 6, no. 3 (March 21, 2017),

\footnotetext{
"Meta Analisis Video Pembelajaran Dalam Menghadapi Tantangan Pendidikan Di Era Revolusi Industri 4.0," Jurnal Penelitian Pembelajaran Fisika 5, no. 1 (December 21, 2019), https://doi.org/10.24036/jppf.v5i1.107421; Eka el Bidayah: Journal of Islamic Elementary Education Volume 3, Nomor 2, September 2021
}

12 Dira Novisya and Festiyed Festiyed, 
findings suggest that with the use of ELearning students are able to manage their own study time by getting teaching materials from their respective places. This learning can train students' independence and hone students' creativity ${ }^{13}$.

In the learning process using ELearning has the same goal, namely to improve student learning outcomes. In addition, it attracts students' attention

\section{Conclusion}

Based on the results and discussion, it can be concluded as follows: the implementation of learning using eLearning videos during the COVID-19 pandemic at SD Negeri 6 Klodan, namely:

1. Learning planning carried out by schools, namely the existence of an emergency curriculum as an adjustment to current conditions, namely carrying out learning using learning videos and e-Learning during the covid19 pandemic. The steps for implementing e-learning are to use supporting applications from e-learning such as the use of learning videos.

2. Analysis of learning outcomes using written test assessments. This is evidenced by an increase in student learning outcomes indicated by the number of students who completed each cycle, namely in the pre-cycle when the test was completed by $27.28 \%$, there was an increase during the test in the first cycle to $54.5 \%$, meaning that there was an increase of $27.22 \%$. In the second cycle the test

https://jurnal.untan.ac.id/index.php/jpdpb/article /view/19182.

${ }^{13}$ Didik Sukanto, "Pembelajaran Jarak Jauh dengan Media E-learning sebagai Solusi Pembelajaran pada Masa Pandemi Coronavirus Disease 2019 (Covid-19)," Syntax Idea 2, no. 11 (November 20, 2020): 834-50, https://doi.org/10.36418/syntax-idea.v2i11.679; 112 with the use of E-Learning, and also makes students happy in learning and achieves complete learning outcomes. With students' interest in a lesson, it will also affect their learning outcomes. The results of the study explain that there is a positive influence on the use of elearning on students' motivation and learning achievement in Yogyakarta Annual Elementary School 14

was completed 91\%, there was an increase in the second cycle, namely an increase of $36.5 \%$. Problems in implementing learning using learning videos and e-Learning during the covid pandemic at SD Negeri 6 Klodan include communication networks such as the difficulty of getting signals, limited internet quotas, measuring affective and psychomotor assessments, lack of motivation from parents given to children. child.

\section{References}

Abidin, Zainul. "Penerapan Pemilihan Media Pembelajaran." Edcomtech Jurnal Kajian Teknologi Pendidikan 1, no. 1 (November 8, 2017): 9-20.

Andrianto, Andrianto. "The Role of Audio Visual Media In Increasing Interst In Learning Islamic Religious Education In Sdn Teloko." Abdau: Jurnal Pendidikan Madrasah Ibtidaiyah 4, no. 1 (July 1, 2021): 71-91. https://doi.org/10.36768/abdau. v4i1.177

\footnotetext{
Muhammad Rusli, Dadang Hermawan, and $\mathrm{Ni}$ Nyoman Supuwiningsih, Memahami E-learning: Konsep, Teknologi, dan Arah Perkembangan (Penerbit Andi, 2020).

${ }^{14}$ Doni Septumarsa Ibrahim and Siti Partini Suardiman, "Pengaruh Penggunaan E-Learning Terhadap Motivasi Dan Prestasi Belajar
}

el Bidayah: Journal of Islamic Elementary Education Volume 3, Nomor 2, September 2021 
Apriyanti, Eka. "Peningkatan Motivasi Belajar Siswa Dalam Pembelajaran Pkn Menggunakan Media Audiovisual Kelas IV." Jurnal Pendidikan Dan Pembelajaran Khatulistiwa 6, no. 3 (March 21, 2017)

https://jurnal.untan.ac.id/index.p $\mathrm{hp} / \mathrm{jpdpb} /$ article/view/19182.

Baharuddin, Ilham. "Pembelajaran Bermakna Berbasis Daring Di Tengah Pandemi COVID-19." Kelola: Journal of Islamic Education Management 5, no. 2 (November 16, 2020): 79-88. https://doi.org/10.24256/kelola. v5i2.1377.

Damayanti, Putri Oktavia. "Efektivitas Media Video Berbasis Powerpoint Dalam Pembelajaran Daring Terhadap Hasil Belajar Tema 7 Subtema 3 Di Kelas IV B MINU Ngingas Waru Sidoarjo." Undergraduate, UIN Sunan Ampel Surabaya, 2021.

http://digilib.uinsby.ac.id/48170/

Gusty, Sri, Nurmiati Nurmiati, Muliana Muliana, Oris Krianto Sulaiman, Ni Luh Wiwik Sri Rahayu Ginantra, Melda Agnes Manuhutu, Andriasan Sudarso, et al. Belajar Mandiri: Pembelajaran Daring di Tengah Pandemi Covid-19. Yayasan Kita Menulis, 2020. Ibrahim, Doni Septumarsa, and Siti Partini Suardiman. "Pengaruh Penggunaan E-Learning Terhadap Motivasi Dan Prestasi Belajar Matematika Siswa Sd Negeri Tahunan Yogyakarta." Jurnal Prima Edukasia 2, no. 1 (January 1, 2014): 66-79. https://doi.org/10.21831/jpe.v2i 1.2645 .

Muhammad Rusli, Dadang Hermawan, and Ni Nyoman Supuwiningsih. Memahami E-learning: Konsep, Teknologi, dan Arah
Perkembangan. Penerbit Andi, 2020.

Novisya, Dira, and Festiyed Festiyed. "Meta Analisis Video Pembelajaran Dalam Menghadapi Tantangan Pendidikan Di Era Revolusi Industri 4.0." Jurnal Penelitian Pembelajaran Fisika 5, no. 1 (December 21, 2019). https://doi.org/10.24036/jppf.v5i 1.107421.

Nugraha, Sobron Adi, Titik Sudiatmi, and Meidawati Suswandari. "Studi Pengaruh Daring Learning Terhadap Hasil Belajar Matematika Kelas IV." Jurnal Inovasi Penelitian 1, no. 3 (July 24, 2020): 265-76.

https://doi.org/10.47492/jip.v1i3 74 .

Nugroho, Dimas, and Yudha Nurdian. "Pemicuan Pendidikan Kecakapan Hidup Anak Era Pandemi di Sumbersari Jember." GERVASI: Jurnal Pengabdian kepada Masyarakat 5, no. 1 (May 2, 2021): 13-24. https://doi.org/10.31571/gervasi .v5i1.1955.

Pohan, Albert Efendi. Konsep Pembelajaran Daring Berbasis

Pendekatan Ilmiah. Riau: Penerbit CV. Sarmu Untung, 2020.

Raniah, Atalah, Jefiska Roman Prantista, Dwi Pangestuti Alfiana, Sangga Firman Aghisni, and Eva Luthfi Fakhru Ahsani. "Dampak Pandemi Terhadap Pemanfaatan ELearning Pada Sekolah Dasar Di Den Haag." Islamic Review: Jurnal Riset Dan Kajian Keislaman 10, no. 1 (April 26, 2021): 111-24. https://doi.org/10.35878/islamic review.v10i1.251.

Rigianti, Henry Aditia. "Kendala Pembelajaran Daring Guru Sekolah Dasar Di Banjarnegara." Elementary School: Jurnal Pendidikan Dan Pembelajaran Ke- 
$S D-A n 7$, no. 2 (July 1,2020$)$.

https://doi.org/10.31316/esjurna l.v7i2.768.

Setyorini, In. "Pandemi COVID-19 Dan

Online Learning: Apakah

Berpengaruh Terhadap Proses

Pembelajaran Pada Kurikulum

13?" Journal of Industrial

Engineering \& Management

Research 1, no. 1 (July 5, 2020):

95-102.

https://doi.org/10.7777/jiemar.v

1i1.31.

Sihombing, Susi, Hizkia Ronaldus

Silalahi, Jonas Ramza Sitinjak, and Hardi Tambunan. "Analisis Minat

Dan Motivasi Belajar, Pemahaman

Konsep Dan Kreativitas Siswa

Terhadap Hasil Belajar Selama

Pembelajaran Dalam Jaringan."

Jurnal Pendidikan

Matematika:Judika Education 4,

no. 1 (June 27, 2021): 41-55.

https://doi.org/10.31539/judika. v4i1.2061.

Sukanto, Didik. "Pembelajaran Jarak Jauh dengan Media E-learning sebagai Solusi Pembelajaran pada Masa Pandemi Coronavirus

Disease 2019 (Covid-19)." Syntax Idea 2, no. 11 (November 20, 2020): 834-50.

https://doi.org/10.36418/syntaxidea.v2i11.679.

Sukmadewi, Ni Putu Rika. "Problem-

Based Learning (Konsep Ideal

Model Pembelajaran dalam

Peningkatan Mutu Prestasi Belajar

dan Motivasi Berprestasi Masa

Pandemi Covid 19)." PINTU: Jurnal

Penjaminan Mutu 1, no. 1 (June 22, 2021).

http://jurnal.stahnmpukuturan.ac .id/index.php/jurnalmutu/article /view/1326.

Susmiati, Eri. “Meningkatkan Motivasi

Belajar Bahasa Indonesia Melalui

Penerapan Model Discovery
Learning Dan Media Video Dalam Kondisi Pandemi Covid-19 Bagi Siswa SMPN 2 Gangga." Jurnal Paedagogy 7, no. 3 (August 13, 2020): 210-15.

https://doi.org/10.33394/jp.v7i3. 2732. 